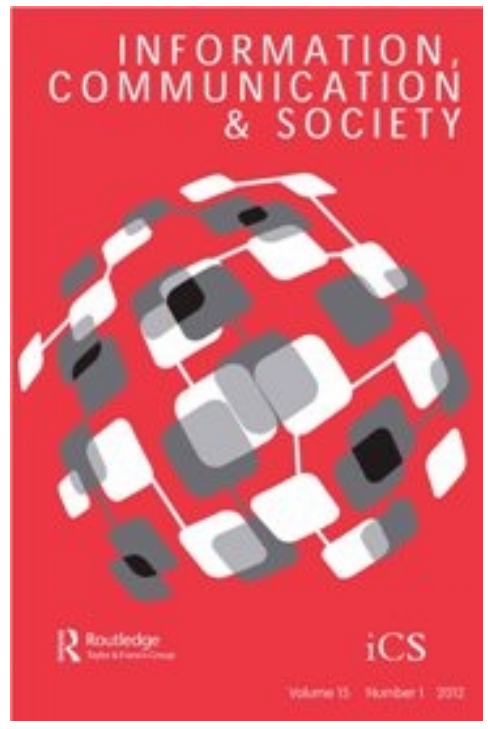

\title{
Reverting trajectories? UKIP's organisational and discursive change after the Brexit referendum
}

\begin{tabular}{|r|l|}
\hline Journal: & Information, Communication and Society \\
\hline Manuscript ID & RICS-2020-0250.R2 \\
\hline Manuscript Type: & Special Issue Paper \\
\hline Keywords: & $\begin{array}{l}\text { UKIP, Far right, Movement parties, Hybridisation, Social Media, Party } \\
\text { change }\end{array}$ \\
\hline
\end{tabular}

\section{SCHOLARONE $^{\text {M }}$ \\ Manuscripts}




\section{Introduction}

The 2016 British referendum on European Union (EU) membership clearly bore momentous consequences. It monopolised the political agenda thereafter, tipping the balance of contention in Brexiteers' favour; and ultimately brought about changes at different institutional levels (Pirro \& Taggart, 2018). After Cameron's resignation as Prime Minister and Leader of the Conservatives (July 2016), it took the United Kingdom (UK) two snap elections and four governments to formally leave the EU in January 2020. The inability of Westminster to deliver Brexit after triggering Article 50 of the EU Treaty testified to a power reconfiguration across British politics, as well as within individual parties. This article specifically focuses on the organisational and discursive changes occurred within the UK Independence Party (UKIP), the main instigator of the Brexit referendum and driving force behind the 'Leave' camp.

UKIP took its first political steps as a cross-party pressure group named Anti-Federalist League and was eventually established as a party in 1993. It gradually evolved from a single-issue hardEurosceptic party to a populist radical right party under the leadership of Nigel Farage (e.g. Taggart, 1998; Ford \& Goodwin, 2014; Usherwood, 2019). After securing its chief political demand, UKIP underwent significant organisational transformation. UKIP leader and Brexit kingmaker Farage initially announced his resignation from office in July 2016. He then quit the party altogether in December 2018, reportedly amid concerns over the new leadership's obsession with English Defence League (EDL) co-founder Tommy Robinson and fixation with the issue of Islam (Dallison, 2018; Davidson \& Berezin, 2018, p. 486). Taking these considerations at face value, the trajectory undertaken by UKIP begs two interrelated questions: How did UKIP turn to the far-right grassroots sector? Did the party shift its discourse in concomitance with these organisational changes? Both organisationally and discursively, it is possible to reconcile UKIP's opening up to far-right movements and activists to the burgeoning literature on 'movement parties' (Kitschelt, 2006) and its discursive shifts to the notion of 'hybridisation' (Chadwick, 2007).

Movement parties are a relatively new species of political party addressing concerns such as the environment and immigration (Gunther \& Diamond, 2003). Most recent examples of movement parties include the far-right Movement for a Better Hungary, the ideologically ambiguous 5 Star Movement in Italy, and the far-left Podemos in Spain (della Porta et al., 2017; Pirro, 2019). These collective actors are essentially 'coalitions of political activists who emanate from social movements and try to apply the organizational and strategic practices of social movements in the 
arena of party competition' (Kitschelt, 2006, p. 280). It is vital for them to pursue political goals 'outside or against the institutionalized channels of political communication and politicians inserted in them' (Kitschelt, 2006, p. 279). While UKIP has invested in the electoral and institutional arenas throughout its political lifecycle, notable changes took place after the Brexit referendum. Unlike other contributions that focused on UKIP's interaction with movements like Britain First (Davidson \& Berezin, 2018), this article examines how the party itself has transformed since 2016. With its recent organisational shift towards the far-right grassroots sector, UKIP seemingly attempted a transition towards the movement-party form.

Organisational and discursive changes may be also driven by a process of hybridisation, according to which established parties would adapt to the digital repertoires of (far-right) movements. Social media are particularly suitable for hybridisation, as new technologies allow for fast 'repertoire switching' between protest and electoral politics (Chadwick, 2007, p. 284). Research on the communication and use of social media by far-right organisations is on the rise (Froio \& Ganesh, 2019; Klein \& Muis, 2019; Berntzen, 2020), although very few of these studies addressed how social media link with hybrid strategies (Davidson \& Berezin, 2018). The study of party change may thus benefit from taking political communication into account: understanding how the far right uses social media adds new insights into its unorthodox politics and forms of mobilisation. With regard to the British case, if the outcome of the Brexit referendum accelerated a process of internal change within UKIP, any shift at the organisational level should in principle reveal change at the discursive level (e.g. Albertazzi et al., 2018; Stockemer and Barisione, 2017).

This article focuses on UKIP's transformation after Brexit and unpacks party strategy as a bundle made of, among other things, organisational and discursive choices. As a first attempt in this direction, the study accounts for developments that have taken place online and offline. Whereas the organisational changes occurring after the Brexit referendum - and especially under the leadership of Gerard Batten (2018-2019) - have perceptibly steered UKIP further towards the right, a concomitant emphasis on 'cultural issues' (i.e. immigration, Islam, and gender) can only be ascertained empirically. Hence, the aim of this article is to describe the reconfiguration of UKIP at the meso level, and analyse changes occurred in its online political communication. While showing UKIP's projection into a new phase of its political lifecycle, the findings qualify the notion that the party has radicalised its (online) discourse as a result of (offline) organisational changes. 


\section{Unpacking UKIP's strategy after the Brexit referendum}

Brexit directly affected the strategy of UKIP, robbing its main and most vocal advocate 'of its central policy issue and of its leader' (Usherwood, 2019, p. 1224). Since 2016, the party has been in constant search for a new identity and new leaders. This highlights the value of focusing on crises as exogenous shocks unfolding at the meso level, and understand how they might affect individual organisations (e.g. Panebianco, 1988; Harmel \& Janda, 1994). The article therefore focuses on the transformation of UKIP under subsequent post-Brexit party leaderships, and addresses how the party has turned to the far-right grassroots sector and adapted its discourse in response to this shift.

The trajectory taken by UKIP after Brexit resonates in good part with the literature on movement parties, though in ways that have not been properly theorised and investigated. As the concept suggests, movement parties are hybrid collective actors whose status is inherently transitional (Kitschelt, 2006; Pirro \& Castelli Gattinara, 2018). Yet, movement parties generally conform to a pattern of movement institutionalisation. Simply stated, movements may decide to take the electoral option while preserving their commitment to street politics. Power and electoral dilemmas would however confront the movement party with questions of survival, ultimately forcing it to opt for institutionalised forms of political action (Panebianco, 1988). Instances of far-right mobilisation across the protest and electoral arenas are not necessarily at odds with each other (Pirro \& Castelli Gattinara, 2018; Castelli Gattinara \& Pirro, 2018; Pirro, 2019), but are unlikely to be evenly sustained over time (Pirro et al., 2019).

The case of UKIP is noteworthy. UKIP stems from the Anti-Federalist League, a cross-party pressure group established in 1991 by British academic Alan Sked, which subsequently evolved into a self-standing political party in 1993. The party lingered at the margins of the British electoral arena until the 2000s, scoring a series of unimpressive results until the accomplishments in the European Parliament (EP) elections of 2004 and 2009 (Ford \& Goodwin, 2014). UKIP's performance reached its peak under the leadership of Farage, gaining over 4.3 million votes (27.5 per cent and 24 seats) in the 2014 EP elections and almost 3.9 million votes (12.6 per cent and one seat) in the 2015 general elections. Its demise after the Brexit referendum has been, on the other hand, quite rapid: UKIP returned an overall 1.8 per cent in the 2017 general elections and an alltime low 0.1 per cent in the 2019 general elections. 
After the Brexit referendum, and the departure of its leader Nigel Farage, the party joined the ranks of other 'weakly organised, poorly led, and divided' British far-right parties (Carter, 2005). Amid internal organisational struggles, and especially under the leadership of Batten (2018-2019), UKIP started flirting with the far-right subculture and opened up to the movement sector. Among other things, Batten's injection of far-right activists into the party was instrumental in establishing War Plan Purple (WPP) as the culturalist branch of UKIP in July 2018. Ultimately, UKIP's drift towards far-right territories prompted former leader Farage to leave the party in late 2018 and form the Brexit Party in early 2019. With the stated objective of delivering UK withdrawal from the EU, the Brexit Party gained the largest share of votes in the 2019 EP election (30.5 per cent). UKIP gained only 3.2 per cent.

UKIP's strategy to enlist far-right activists within its ranks and invest in parallel grassroots organisations is theoretically coherent with a shift towards the movement-party form and practically compatible with the rise of a more radical faction within the party. UKIP has a long-standing story of internal factionalism. Already by the late 2000s, when UKIP broadened its policies to immigration and multiculturalism, the party leadership faced the internal resistance of members solely concerned with UK withdrawal from the EU (Ford \& Goodwin, 2014; Hanna \& Busher, 2019; Usherwood, 2016).

UKIP's opening up to street politics and grassroots movement actors is however unprecedented, and its occurrence at such a late stage in its political lifecycle is fairly unique. Furthermore, reversing movement-party trajectories has not been covered by theories of movement-electoral interactions (McAdam \& Tarrow, 2010; Pirro, 2019). To be sure, the far right might take movement-party features without necessarily stemming from the movement sector (Kitschelt, 2006). But if moves along the movement-party continuum are to be interpreted as a one-way progression leading to transformation into political party, UKIP made investments to revert this monodirectional course. This primarily materialised through organisational change.

The contemporary far right has demonstrated high margins of adaptability. For each strategic turn involving organisational or leadership change, a shift in discourse has almost invariably followed. This applies indistinctly to movement parties and fully institutionalised parties (Widfeldt, 2008; Stockemer \& Barisione, 2017; Albertazzi et al., 2018; Pirro, 2019). The analytical portion of this article is therefore concerned with discursive change, and asks whether UKIP's discourse adapted to its organisational shift further to the right. It is worth noting that Farage left UKIP in 2018 
claiming that its new leader, Gerard Batten, was increasingly obsessed with Islam and anti-Muslim policies (Walker, 2018a). The expectation would therefore be that UKIP under Batten has adjusted its discourse and started giving more prominence to far-right 'cultural issues' such as immigration, Islam, and gender over topics such as the EU and Brexit.

\section{H1: Under Batten's leadership, UKIP's discourse emphasised cultural issues over 'Europe'.}

UKIP under Batten seemed fascinated with Gramsci's notion of 'cultural hegemony', to be interpreted here as a means to challenge the intellectual and cultural dominance of the left and the liberal-democratic status quo (e.g. Griffin, 2000). In the online sphere, the establishment of WPP seemed to respond to similar purposes: between 2018 and 2019, WPP presented itself as a direct emanation of UKIP 'on the front lines of the culture war'. ${ }^{1}$ While ascertaining organisational continuity between UKIP and WPP, it may as well be that, under the mounting pressure of internal factionalism, Batten tried to diversify UKIP's communication strategy to appease the more liberal faction of the party, or simply address different audiences: a mainstream audience made of traditional UKIP voters and a subcultural radical audience endorsing cultural issues. Hence, one could expect that, during Batten's leadership, cultural issues were primarily voiced by WPP, instead of UKIP.

\section{H2: During Batten's leadership, WPP placed more emphasis on cultural issues than UKIP.}

The organisational and discursive changes outlined so far can be reconciled with the hybridisation encouraged by the internet. On social media, actors can swiftly adapt forms, change identities, and switch action repertoires. These opportunities effectively propelled new, hybrid, forms of activism (Chadwick, 2007). The creation of a new 'wing' of UKIP under Batten, specifically organised by, and tailored for, tech-savvy alt-right and online activists, fits this idea and is consistent with UKIP's attempt to rebrand itself. This study tests these hypotheses through UKIP's and WPP's communication on Twitter.

Through social media platforms, far-right actors can spread their views without the filter of the traditional media. Social media platforms helped far-right movements like the EDL and PEGIDA gain support and organise rallies (Berntzen \& Weisskircher, 2016). Social media are considered a successful tool for far-right parties in particular, as these platforms favour highly emotional,

\footnotetext{
${ }^{1}$ https://twitter.com/warplanpurple.
} 
simplified, and dramatised content (Engesser et al., 2017, p. 1313). Their non-hierarchical nature and the opportunity to speak directly to the people without a media filter fit well the populist ideals of these actors (Bartlett, 2014, p. 106; Engesser et al., 2017, p. 1286).

Twitter represents a vehicle for unmediated communication and one of the most important political outreach tools for far-right parties and leaders (Van Kessel \& Castelein, 2016; Larsson \& Moe, 2012; Jacobs \& Spierings, 2016). Research on online communication has often focused on Twitter, a platform that offers relatively easy access to scholars, but with a much smaller and more specific demographic than other social media platforms (Cihon \& Yasseri, 2016). Twitter reaches, however, a broader audience than traditional media as the platform is an important source for journalists (Stier et al., 2018; Engesser et al., 2017). The platform has several features that makes it suitable for political communication. The opportunity to search for keywords and hashtags as well as the availability of retweet buttons easily allows one to spread content across the network (Halupka, 2014, p. 162; Bossetta, 2018, p. 476). The option to share links underlines that Twitter is a suitable medium for communicating information to followers (Bossetta, 2018). It has thus been described as a platform primarily used for information consumption and distribution (Hermida, 2010). Social media, and Twitter in particular, offer an additional advantage: unlike political manifestos, which are issued in concomitance with elections (Budge et al., 1987), they deliver a regular stream of political views on multiple subjects and represent effective tools for self-promotion (Golbeck et al., 2010). As the timeframe of analysis rests on leadership changes, rather than elections, Twitter provides a very sensitive platform for studying the effects of these changes.

\section{Research design, data, and methods}

The article is concerned with UKIP's transformation after Brexit. It thus examines the changes occurred in the organisation and online discursive practices across leadership periods. Tackling organisational change responds to a descriptive objective, and is assessed qualitatively by reconstructing UKIP's network composition after Brexit. To analyse how organisational change influenced shifts in discourse, tweets were collected from the accounts of UKIP and War Plan Purple, covering the period between January 2015 and May 2019. Data were gathered through the Twitter API using the Python libraries Tweepy and Selenium (Roesslein, 2017). Besides the content of the tweet, the data reported the time-date stamp of the post, the number of likes, replies, and retweets that each tweet received. A total of 12368 tweets were posted on the page of UKIP 
between January 2015 and May 2019. From its establishment in July 2018 until May 2019, 3731 tweets were extracted from the page of WPP.

For the purpose of this study, retweets and replies were filtered out of the data. This proved necessary as the number of replies was especially high for WPP. More than 50 per cent of the tweets collected from this page were retweets. Most of these replies seemed to reflect a trolling culture aimed at bashing users. Tweets solely consisting of a link and/or emoji were also filtered out as these could not be analysed automatically. The analysis therefore reflects only the textual content posted on the Twitter accounts of UKIP and WPP, namely a selection of 10816 tweets for UKIP and 914 tweets for WPP (Table 1).

\section{[TABLE 1 HERE]}

Table 1 provides an overview of UKIP and WPP pages, and the interaction of users on them. WPP interacted much more with their followers, as most of the tweets consisted of replies to other users. Conversely, UKIP was geared towards delivering information, as less than 2 per cent of its tweets consisted of replies. UKIP on average enjoyed more interactions in terms of likes, replies, and retweets by users. However, looking at the higher number of UKIP followers, it is possible to conclude that WPP had a comparatively higher engagement. Interesting differences emerge comparing the tweets and engagement of users on the page of UKIP over the different leadership periods. Under Steve Crowther and Gerard Batten, UKIP interacted more with users than under other leaders: replies during these periods amount to about 7.5 and about 9 per cent of tweets, respectively. UKIP under Nigel Farage, Diane James, and Paul Nuttal had very few replies (less than 1 per cent of all tweets); even under Henry Bolton, this figure was less than 3 per cent. The number of engagements that UKIP received under Batten is remarkable: likes, replies, and shares experienced a threefold increase compared to the previous leadership period. While more interactions could be due to the growing number of followers, they may also testify UKIP's greater investments in the online sphere during Batten's leadership.

Discursive change is assessed in terms of shifts in issue salience. To illustrate the results, the study reports quotes based on a qualitative reading of all tweets for any given topic. The topics included relate to European issues and cultural issues, i.e. immigration, Islam, and gender. This research strategy notably expands on previous studies that focused on the salience of the EU and immigration in UKIP's press releases and media coverage (Usherwood, 2019). Due to the brevity of 
many tweets, the quantitative analysis relied on a dictionary approach instead of a topic modelling approach (cf. Puschmann \& Scheffler, 2016). Dictionaries were created ad hoc, based on the reading of UKIP electoral manifestos between 2009 and 2018, as well as tweets from UKIP and WPP pages (Table 2). These dictionaries were refined by comparing the outcomes of the dictionary classification with those by a human coder. Keywords were added to or removed from the dictionaries on the basis of potential inconsistencies. This process was repeated several times to improve the precision (i.e. how often a tweet that is identified by the dictionary is also about the topic of the dictionary) and recall (i.e. how often the dictionary fails to detect relevant tweets) of the dictionaries. Table 3 outlines the precision, recall, and F1 measures for the dictionaries used in this study. These measures are based on a manual coding of 300 randomly selected tweets (see also Sheafer et al., 2014).

\section{[TABLE 2 HERE]}

\section{[TABLE 3 HERE]}

Data were pre-processed using the Quanteda package in R to remove numbers, punctuation, links, stopwords, and set the characters to lower cases (Benoit et al., 2018). The package was used to count how often each dictionary occurred in the tweets, indicating whether at least one word in the dictionary was present in the tweet (1) or not (0). Independent t-tests with Bonferroni corrections were carried out to see whether the mean number of tweets discussing the different topics significantly changed on the page of UKIP before and during Batten's leadership (H1). Finally, ttests were conducted to ascertain differences in issue salience between the Twitter pages of UKIP and WPP during Batten's leadership period (H2).

\section{Organisational change}

UKIP's electoral growth under the leadership of Farage largely put internal dissent to rest. His demise after the Brexit referendum, however, projected the party into a soul search punctuated by several personnel changes and defections. Diane James was UKIP's leader-elect between September and October 2016, but resigned before taking office. Farage continued serving as acting leader until the 2016 leadership election. Paul Nuttall was elected as new leader in November 2016, but resigned in June 2017 after failing to win a seat in the general elections. Henry Bolton was 
chosen over Anne Marie Waters in the 2017 leadership election. Waters is the founder and director of Sharia Watch UK; in 2016, she launched PEGIDA UK with Tommy Robinson and former UKIP candidate Paul Weston. She left UKIP after the leadership election, and went on to form and lead the far-right party For Britain. Bolton held office until February 2018, when he was ousted following a controversy over racist comments. Gerard Batten was elected in April 2018 and remained in office until UKIP's disappointing performance at the 2019 EP election.

Across these leadership changes, UKIP also experienced a drain of members. From the 34,000 members reported by the Electoral Commission in December 2016, the party went down to 18,000 by February 2018. This trend was reverted upon Batten's election to chairman, when UKIP allegedly bounced back to about 30,000 members. ${ }^{2}$ Such an increase is associated to Batten's investments to attract far-right activists within party ranks (Walker, 2018b; Walker \& Halliday, 2019). In this regard, a notable development was Tommy Robinson's appointment to Batten's personal advisor in November 2018. A former British National Party (BNP) member, Robinson (born Stephen Yaxley) is the founder and former leader of EDL - a far-right movement that gained significant exposure and following in the early 2010s for its vocal opposition to Islam (Busher, 2015). Robinson left EDL in 2013 but later set up the British chapter of PEGIDA. While not a formal member of UKIP, he stood as independent candidate at the 2019 EP elections, also earning the support of Anne Marie Waters (Halliday, 2019). Robinson's nomination took place in open defiance of UKIP's rulebook, which prevents members of far-right organisations like EDL to join the party (UKIP, 2018). Such a move seemed to testify a radicalisation of the party, anticipating the prominence of anti-Muslim discourses in UKIP's campaigning (Payne, 2018).

Another move substantiating UKIP's organisational change included allowing social media activists Paul Joseph Watson, Mark Meechan, Carl Benjamin, and Milo Yiannopoulos into the party in the summer of 2018 (Walker, 2018c; Spence \& Di Stefano, 2019). The four far-right activists have large online followings and have expressed controversial views. Watson's YouTube channel, PrisonPlanetLive had 1.6 million subscribers as of June 2019. He uttered anti-Muslim and antiimmigrant opinions and is also senior editor at InfoWars, a US-based website that deals in conspiracy theories and promotes fake news. The website, founded by Alexander Jones, was launched in 1999 and has a monthly reach of 10 million visits. Meechan, also known as Count Dankula, is a Scottish YouTuber with over half a million subscribers. He was fined $£ 800$ in early 2018 for posting a video of a pug dog giving Nazi salutes. Meechan ran as candidate on the UKIP

\footnotetext{
${ }^{2}$ Gerard Batten on BBC's Andrew Marr Show, 14 April 2019.
} 
list in Scotland for the 2019 EP election. Benjamin is a conspiracy theorist and anti-feminist, who expressed views against Islam and political correctness. He is best known online as Sargon of Akkad. His YouTube channel lists almost one million subscribers at the time of writing. Benjamin also ran as UKIP candidate at the 2019 EP election. Finally, Yiannopoulos was the technology editor of the far-right Breitbart News Network and gained fame after he was suspended from Twitter over the abuse of actress Leslie Jones. Yiannopoulos was one of the key figures of the American alt-right and played a big role in the misogynist Gamergate movement online. He reportedly joined Benjamin on his campaign trail for the 2019 EP elections (Spence \& Di Stefano, 2019).

The enrolment of these (online) activists is directly connected to the establishment of War Plan Purple as the cultural wing of UKIP in July 2018. WPP represented 'UKIP's new social mediasavvy demographic of the nation' (Kipper Central, 2018), organising protests and speaking at rallies. WPP has both a Twitter and Facebook page ${ }^{3}$, as well as a closed Facebook group. ${ }^{4}$ The group first affiliated with the party by showing 'UKIP' in its logo. After Batten's tenure, however, WPP is no longer affiliated to the party and renamed itself from 'UKIP Liberalists' into 'UK Liberalists'.

Throughout this period, UKIP's Facebook and Twitter pages both followed and liked WPP on social media, and UKIP mentioned WPP in several of its tweets. WPP is linked to The Liberalists (or The Liberalist Society), a movement focused on activism - mostly in the form of events, protests, activities, and international campaigns - whose main goal is to 'uphold, promote, and spread classical Liberalism'. ${ }^{5}$ In their own understanding, 'the term is a declaration of opposition to collectivist ideologies such as socialism, communism, feminism, Islamism and fascism' ${ }^{6}$ The Liberalists draw inspiration from Carl Benjamin's own articulation of the seven 'Liberalist Principles', i.e. individual rights, democracy, economic freedom, freedom of speech, self-reliance, blind justice, and secularism. ${ }^{7}$ Therefore, between 2018 and 2019, there has been organisational continuity between The Liberalists, WPP, and UKIP. The injection of new activists under Batten's leadership is indeed central to unravel developments at the discursive level presented in the following section.

\footnotetext{
${ }^{3}$ https://www.facebook.com/WarPlanPurple.

${ }^{4}$ https://www.facebook.com/groups/UKIPLiberalists.

5 The quote was retrieved from http://theliberalists.net/about in June 2019. The Liberalists now only have one registered domain (http://liberalists.org), which does not include an 'About' section.

${ }^{6} \mathrm{http}: / /$ liberalists.org/faq/.

${ }^{7}$ http://liberalists.org/principles/.
} 


\section{Discursive change}

How did UKIP's issue focus change over time? How did the Brexit referendum and subsequent leadership changes affect the discourse of the party? Figure 1 shows UKIP's issue focus on Twitter, over time. Figure 2 illustrates how issue salience was distributed on the page of UKIP and the affiliated War Plan Purple during Batten's leadership. The figures were generated with the R package Ggplot2 (Wickham, 2016).

\section{[FIGURE 1 HERE]}

\section{[FIGURE 2 HERE]}

Out of all changes ensuing after the Brexit referendum, the article hypothesised a shift in issue salience under Batten's leadership. In light of the recruitment of far-right activists within UKIP ranks, the first hypothesis anticipated cultural issues to override concerns over 'Europe' and Brexit. To test whether such changes took place under Batten, a t-test with Bonferroni corrections was carried out to compare the discourse of UKIP before Batten became leader (Table 4). Only the leaders after Farage were included in the analysis.

\section{[TABLE 4 HERE]}

Compared to previous leadership periods, UKIP under Batten did not significantly differ in the salience of immigration, Islam, and gender (Table 4). During the leadership of Nuttal, for example, UKIP denied allegations of racism, but also denounced excessive political correctness, arguing that the party supporters shall 'stop being scared of being called names' ${ }^{8}$ Under Bolton, transgender people turned into a political target and gender was used to attack political elites. Politicians were blamed for 'transgenderism', and the government was seen to 'push transgender books on primary schools'. ${ }^{10}$ Debates on gender change were heated, as in a post arguing that 'declaring your sex as optional' was 'madness'. ${ }^{11}$ A similar discourse on transgender issues continued under Batten. One

\footnotetext{
${ }^{8}$ https://twitter.com/UKIP/status/872011917279219712.

${ }^{9} \mathrm{https}: / /$ twitter.com/UKIP/status/943169369709916160.

${ }^{10} \mathrm{https}: / /$ twitter.com/UKIP/status/940937131282792449.

${ }^{11} \mathrm{https}: / /$ twitter.com/UKIP/status/917391388668518400.
} 
tweet described gender-affirmation treatment of young children as 'child abuse of the highest order'. ${ }^{12}$ The discourse even went as far as describing transgender people as a threat. This was the case for a news item about a woman sexually abused by a transgender inmate in an all-female prison. The tweet stated that UKIP has 'warned countless times' for the danger of such 'obsessive virtue signalling' ${ }^{13}$

There was no statistically significant difference in the frequency with which Islam was discussed before and during Batten's mandate as a UKIP leader. The issue was already addressed on Twitter before his leadership. During Nuttal's tenure, for example, Sharia courts were a point of discussion, as was Islamic fundamentalism, which was described as a 'dangerous cancer in our society'. ${ }^{14}$ Under the leadership of Bolton, then, the issue of Islam was framed as a cultural threat, stating how the 'appeasement of Islam' threatens Christianity'. ${ }^{15}$ These pleas reflected quite clearly in other tweets, whereby 'people are concerned about rising tide of Islam in communities' ${ }^{16}$ The discourse did not change substantively under Batten, as UKIP reiterated the fear of an Islamic takeover. Several tweets mentioned that 'Britons are being converted to literalist Islam - this is a major threat to our country. We cannot be silent any longer'. ${ }^{17}$ Another post argued that veils were 'weaponised by Islamists' so as to 'impose [an] Islamic character on communities'. ${ }^{18}$ In a more 'liberal' spell (Berntzen, 2020), tweets voiced the danger that Islam posed to Western society, specifically to homosexuals and Jews.

The findings overall show a clear and significant increase in salience of European issues and Brexit under Batten ( $\mathrm{t}=-15.69 * * *)$. This evidence goes against the expectations formulated in $\mathrm{H} 1$, and against the notion that UKIP transformed into a far-right organisation 'fixated with Islam' under Batten's leadership. While proving that the delivery of Brexit remained a prime concern for UKIP, the analysis also corroborates that UKIP had emphasised anti-immigration stances long before Batten's tenure (e.g. Ford \& Goodwin, 2014).

Delving deeper into these aspects, it is worth asking: How does this trend compare to the prereferendum period? Was UKIP's communication under Farage, and before the Brexit referendum,

\footnotetext{
12 https://twitter.com/UKIP/status/1115746893064228864.

13 https://twitter.com/UKIP/status/1037991569872302082.

${ }^{14} \mathrm{https}: / /$ twitter.com/UKIP/status/862741940235841536.

15 https://twitter.com/UKIP/status/940880382546849799.

16 https://twitter.com/UKIP/status/937034996224806912.

${ }^{17} \mathrm{https}: / /$ twitter.com/UKIP/status/1027931141762899968.

18 https://twitter.com/UKIP/status/1028935059049459713.
} 
substantively different? The t-test, evaluating the issue salience before and after the referendum, seems to reflect a similar focus on Europe (Table 5). Findings indicate that the issue of Islam became more common in tweets after the referendum $\left(\mathrm{t}=-3.38^{* *}\right)$. Yet, the mean number of tweets focusing on this issue is still very low, and much lower than the issues of immigration and Europe. Reference to European issues also strongly increased after the referendum $(\mathrm{t}=-3.74 * * *)$. Against this backdrop, immigration was discussed more often before the referendum took place $(\mathrm{t}=7.74 * * *)$.

\section{[TABLE 5 HERE]}

Despite the attention devoted to immigration before the Brexit referendum, UKIP's account referred to the 'non-racist \& non-sectarian' nature of the party ${ }^{19}$, stating that extremist comments on Islam or any other religion - were 'totally unacceptable'. ${ }^{20}$ This notwithstanding, UKIP under Farage argued that 'In almost every area, net migration, overall UK immigration, EU immigration, non-EU immigration, the government has failed catastrophically'. ${ }^{21}$ This paired with concerns such as: 'Rapid implementation of common EU migration and asylum policy could lead to Islamic extremists coming to the UK'.22

There was no statistically significant difference in the frequency with which gender was discussed before and after the referendum. However, there seems to be a qualitative shift in the discussion on gender. Gender primarily referred to issues of gay and women's rights under Farage's leadership. UKIP once had its own LGBT section, and the discourse on homosexuality and women was neutral if not outright positive. The page included posts such as 'UKIP and homosexuality: a gay member's view' or stated that UKIP was not against gay adoption. ${ }^{23}$ On the issue of women's right, UKIP engaged in posts such as 'we think women are smart enough to get by on merit. They do in UKIP' or 'A female UKIP Councillor makes the case for why the party isn't an old boys' club'. ${ }^{24}$ These are notable qualitative differences between successive leaderships.

Since discursive change on cultural issues is not clearly discernible after the Brexit referendum, it is interesting to evaluate whether immigration, Islam, or gender were 'outsourced' to WPP, UKIP's cultural wing under Batten (H2). To test this second hypothesis, the analysis compared the tweets of

\footnotetext{
${ }^{19} \mathrm{https}: / /$ twitter.com/UKIP/status/179533286350139393.

${ }^{20} \mathrm{https}: / /$ twitter.com/UKIP/status/190773608677781504.

${ }^{21} \mathrm{https}: / /$ twitter.com/UKIP/status/601322712431206400.

$22 \mathrm{https} / / /$ twitter.com/UKIP/status/593343864301301760.

${ }^{23} \mathrm{https} / / /$ twitter.com/UKIP/status/274171260966146048.

${ }^{24} \mathrm{https}: / /$ twitter.com/UKIP/status/402735603500208129; https://witter.com/UKIP/status/367211481953075200.
} 
UKIP and WPP exclusively under Batten's leadership period (2018-2019). Table 6 confirms that the pages overall focused on different issues. European issues are discussed much more often by UKIP ( $\mathrm{t}=19.42 * * *)$, while cultural issues are consistently discussed more often by WPP. This is the case for immigration $(\mathrm{t}=-2.67 *)$, Islam $(\mathrm{t}=-6.49 * * *)$, and gender $(\mathrm{t}=-3.92 * * *)$. Generally speaking, the idea of discursive diversification across multiple platforms is consistent with the findings: WPP's page discussed all cultural issues more often than UKIP (H2), which in turn placed significantly more emphasis on European issues. Even under Batten, UKIP seemed then concerned with discursive continuity, possibly not to estrange its traditional voter base or appease the more liberal faction of the party.

\section{[TABLE 6 HERE]}

For example, WPP delivered a harsher stance on gender compared to UKIP. The page asked 'whether it is acceptable to encourage children to be gay'"25, and stating that 'most women are not retarded'26 and that 'half of misogynistic tweets [are] sent by women'. ${ }^{27}$ At times, the discourse took a conspiracist flair, with posts such as 'kids as young as three are being sent to an NHS transgender clinic accused of 'live experimenting' on them'. ${ }^{28}$ At the same time, WPP used a protective frame towards women, stating that migrants had to be stopped otherwise they would rape women. Similarly, a tweet appeared on the WPP page about homosexuals being 'badly beaten in Paris by refugees for the crime of being gay'. ${ }^{29}$ The link between paedophilia and Islam returns quite often, using terms such as 'Islamic grooming gangs' to describe how 'Pakistani Muslim rape gangs' targeted 'non-Muslim girls as young as 11 for sexual abuse'. ${ }^{30}$ In addition to these issues, WPP adopted a 'political correctness' frame, blaming the elites for looking away and flinching from speaking up about the problematic aspects of the Islam.

The evidence presented therefore corroborates that, even before Batten's rise to chairman, UKIP had done little to disprove allegations of far-right leanings at the discursive level, but actually attempted to normalise abusive rhetoric on gender and Islam. The subscription to radical views was more apparent on the Twitter account of WPP, UKIP's cultural wing during Batten's leadership. During this period, WPP moved indistinct attacks against Muslims, feminists, and LGBTQ people,

\footnotetext{
25 https://twitter.com/WarPlanPurple/status/1030018958563389440.

${ }^{26} \mathrm{https}: / /$ twitter.com/WarPlanPurple/status/1093946696076271616.

${ }^{27} \mathrm{https}$ ://twitter.com/WarPlanPurple/status/1125671030964535301.

${ }^{28} \mathrm{https}: / /$ twitter.com/WarPlanPurple/status/1115735893124558849.

${ }^{29} \mathrm{https}: / /$ twitter.com/WarPlanPurple/status/1052561253980430336.

${ }^{30} \mathrm{https} / / /$ twitter.com/WarPlanPurple/status/1054012954901991426.
} 
using a discourse that was, in all probability, deemed too extreme for a more mainstream audience of over 200,000 UKIP followers.

\section{Discussion and conclusions}

The Brexit referendum bore seismic consequences for UK politics. UKIP, as the most vocal and recognisable advocate of UK withdrawal from the EU, was swiftly projected into chaos after securing its main political goal. Farage's decision to step down from leadership in 2016 and leave the party in 2018 further contributed to internal instability. Since 2016, UKIP saw no less than eight leaders in office amid declining membership and consensus. During his stint as UKIP leader, Batten responded to these challenges trying to impose a change of strategy. Such a strategy first and foremost entailed opening up to far-right grassroots politics. Commentators widely anticipated a 'far-right turn' in UKIP's campaigning (Walters, 2018a). The article therefore reconstructed the organisational changes underlying this turn and assessed the discursive implications of far-right activists' recruitment. These aims resonate with the scholarship on movement parties and, even more so, with the hybridisation of action repertoires.

At the organisational level, enlisting far-right activists entailed opening up to the grassroots sector, both offline and online. The appointment of Tommy Robinson as Batten's personal advisor and the establishment of War Plan Purple as the cultural wing of UKIP were, in this sense, paradigmatic and substantiated a movement-party turn. This challenged standards and practices of movementelectoral interactions as UKIP provisionally reverted its institutional trajectory to venture down a social-movement route. Most interestingly, it did so at a rather late and consolidated stage of its political lifecycle.

At the discursive level, a significant far-right turn in UKIP's communication - as for prevalence of cultural over European issues - did not quite materialise. First, while European issues remained firmly at the heart of UKIP's discourse throughout the period analysed, it is also true that cultural issues were already salient before Batten stepped in as chairman. The analysis showed that preBatten's UKIP was more concerned with immigration than Batten himself, prompting to reconsider the magnitude of discursive change occurred under his leadership. A stronger emphasis on cultural issues was however visible on the page of WPP. Through the establishment of WPP, Batten and UKIP took on a more hybrid approach, diversifying their communication. By means of this 
strategy, WPP served as a platform to engage UKIP supporters attracted by extremist ideas, while keeping UKIP clear from (further) controversy. Batten was however unable to gain the upper hand over UKIP's more liberal faction and impose his vision as a long-term strategy. Internal infighting within UKIP ultimately forced Batten and his successor, Richard Braine, to resign from the party (Cockburn, 2019). With their departure, WPP also discontinued its affiliation to UKIP. This notwithstanding, UKIP has temporarily provided a platform for far-right activists and vloggers, whose extremist ideas propagated across mainstream political circles. Through this time period, UKIP and WPP filled a discursive gap after the BNP, Britain First, and EDL were censored from social media platforms (Hern, 2019).

The article unpacked party change as a bundle of organisational and discursive strategies, encouraging to factor in, and delve into, the activist component of far-right politics. This study also went the extra mile to review qualitative shifts in discourse, thus moving beyond assessments purely based on shifts in issue salience. For instance, while the analysis did not detect significant quantitative changes in issues like gender and Islam, it highlighted a radical turn in the way these issues were discussed across subsequent leadership periods. The study generally rested on the assumption that communication on Twitter is a representative proxy for the ideological stances of individual organisations and those of their leaders. However, alternative approaches could also probe the personal profiles of leaders on Twitter and other social media, as well as the discursive practices of their followers.

Further research should finally consider whether movement-party hybridisation is part of a broader process within the far right. From the French Front National onwards, the history of the contemporary far right abounds with instances of mobilisations occurring in both the protest and electoral arenas (Pirro, 2019). More critically, reverting trajectories seems possible and, as the Flemish Vlaams Belang has shown, opening up to the movement sector decades after its foundation can also bear significant electoral fruits. The recruitment of Dries van Langehoven, the founder of the youth movement Schild \& Vrienden, as well as a fine-tuned online communication strategy could in part explain their recent electoral comeback (Cerulus, 2019). However, the recent ousting of Der Flügel from the Alternative für Deutschland (Müller, 2020) shows that the establishment of a radical wing is not always, nor necessarily, a successful endeavour.

The study of movement parties and hybridisation processes represents a new frontier in far-right research. Focusing on such aspects requires swift and timely effort, not least due to the often- 
transitory nature of cooperation among different far-right actors or the ever-more stringent criteria set by social media with regard to incitement of hatred. Notwithstanding these potential limitations, studies have shown that networks matter as do platform architectures for the discourse that is presented (e.g. Bossetta, 2018; Pirro et al., 2019). While this study concentrated on party change at a particular juncture, the boundaries between online and offline mobilisation have become porous and this holds especially true for the far right and its reduced ability to access mainstream media. 


\section{References}

Albertazzi, D., Giovannini, A., \& Seddone, A. (2018). 'No regionalism please, we are Leghisti!' The transformation of the Italian Lega Nord under the leadership of Matteo Salvini. Regional \& Federal Studies, 28(5), 645-671.

Bartlett, J. (2014). Populism, Social Media and Democratic Strain. In C. Sandelind (Ed.), European populism and winning the immigration debate (pp. 99-114). Stockholm: Fores.

Benoit, K., Watanabe, K., Wang, H., Nulty, P., Obeng, A., Müller, S., \& Matsuo, A. (2018). Quanteda: An R package for the quantitative analysis of textual data. Journal of Open Source Software, 3(30), 774.

Berntzen, L.E. (2020). Liberal Roots of Far Right Activism: The Anti-Islamic Movement in the 21 ${ }^{\text {st }}$ Century. London: Routledge.

Berntzen, L. E., \& Weisskircher, M. (2016). Anti-Islamic PEGIDA beyond Germany: Explaining differences in mobilisation. Journal of Intercultural Studies, 37(6), 556-573.

Bossetta, M. (2018). The digital architectures of social media: Comparing political campaigning on Facebook, Twitter, Instagram, and Snapchat in the 2016 US election. Journalism \& Mass Communication Quarterly, 95(2), 471-496.

Budge, I., Robertson, D., \& Hearl D. (1987). Ideology, Strategy and Party Change: Spatial Analyses of Post-War Election Programmes in 19 Democracies. Cambridge: Cambridge University Press.

Busher, J. (2015). The Making of Anti-Muslim Protest: Grassroots Activism in the English Defence League. London: Routledge.

Carter, E. (2005). The Extreme Right in Western Europe: Success or Failure? Manchester: Manchester University Press.

Castelli Gattinara, P., \& Pirro, A.L.P. (2019). The far right as social movement. European Societies, 21(4): 447-462.

Cerulus, L. (2019). Inside the far right's Flemish victory. Politico. Retrieved from https://www.politico.eu/article/inside-the-far-rights-flemish-victory/.

Chadwick, A. (2007). Digital network repertoires and organizational hybridity. Political Communication, 24(3): 283-301.

Cihon, P., \& Yasseri, T. (2016). A biased review of biases in Twitter studies on political collective action. Frontiers in Physics, 4: 34. 
Cockburn, H. (2019, October 30). Ukip loses eighth leader since Brexit referendum as Richard Braine resigns ahead of general election. Independent. Retrieved from https://www.independent.co.uk/news/uk/politics/richard-braine-ukip-leader-resign-brexitgeneral-election-latest-a9177516.html.

Dallison, P. (2018, April 12). Nigel Farage quits UKIP. Politico. Retrieved from https://www.politico.eu/article/nigel-farage-quits-ukip/.

Davidson, T., \& Berezin, M. (2018) Britain First and the UK Independence Party: Social media and movement-party dynamics. Mobilization: An International Quarterly, 23(4): 485-510.

della Porta, D., Kouki, H., Fernandez, J., \& Mosca, L. (2017). Movement Parties against Austerity. Cambridge: Polity Press.

Engesser, S., Ernst, N., Esser, F., \& Büchel, F. (2017). Populism and social media: How politicians spread a fragmented ideology. Information, Communication \& Society, 20(8), 1109-1126.

Ford, R., \& Goodwin, M.J. (2014). Revolt on the Right: Explaining Support for the Radical Right in Britain. London: Routledge.

Froio, C., \& Ganesh, B. (2019). The transnationalisation of far right discourse on Twitter. European Societies, 21(4): 513-539.

Golbeck, J., Grimes, J., \& Rogers, A. (2010). Twitter use by the U.S. Congress. Journal of the American Society for Information Science and Technology, 61(8): 1612-1621.

Griffin, R. (2000). Interregnum or endgame? The radical right in the 'post-fascist' era. Journal of Political Ideologies, 5(2): 163-178.

Halliday, J. (2019, April 25) Tommy Robinson announces plans to stand as MEP. Guardian. Retrieved from https://www.theguardian.com/uk-news/2019/apr/25/tommy-robinson-standmep-manchester-event-community-leaders-condemn-anti-islam-activist.

Halupka, M. (2014). Clicktivism: A systematic heuristic. Policy \& Internet, 6(2), 115-132.

Hanna, J., \& Busher, J. (2019). UKIP and the UK's radical right: A tale of movement party success? In M. Caiani \& O. Císar (Eds.), Radical Right Movement Parties in Europe (pp. 46-62). London: Routledge.

Harmel, R., \& Janda, K. (1994). An integrated theory of party goals and party change. Journal of Theoretical Politics, 6(3): 259-287.

Hermida, A. (2010). From TV to Twitter: How ambient news became ambient journalism. Media/Culture Journal, 13(2): 1-6. 
Hern, A. (2019, April 18). Facebook bans far-right groups including BNP, EDL and Britain First. Guardian. Retrieved from https://www.theguardian.com/technology/2019/apr/18/facebookbans-far right-groups-including-bnp-edl-and-britain-first.

Jacobs, K., \& Spierings, N. (2016). Social Media, Parties, and Political Inequalities. Basingstoke: Palgrave Macmillan.

Kipper Central (2018, August 20). EXCLUSIVE: Who Are War Plan Purple? Retrieved from https://kippercentral.com/2018/08/20/kipper-central-exclusive-who-are-war-plan-purple/.

Kitschelt, H. (2006). Movement parties. In R.S. Katz, \& W.J. Crotty (Eds.), Handbook of party politics (pp. 278-90). Thousand Oaks: Sage Publishing.

Klein, O., \& Muis, J. (2019). Online discontent: comparing Western European far-right groups on Facebook. European societies, 21(4), 540-562.

Larsson, A., \& Moe, H. (2012). Studying political microblogging: Twitter users in the 2010 Swedish election campaign. New Media \& Society, 14(5): 729-747.

McAdam, D., \& Tarrow, S. (2010). Ballots and barricades: on the reciprocal relationship between elections and social movements. Perspectives on Politics, 8(2): 529-542.

Müller, A. (2020, March 21). Der Flügel flattert weiter. Der Spiegel. Retrieved from https://www.spiegel.de/politik/deutschland/afd-der-fluegel-flattert-trotzaufloesungsbeschluss-weiter-a-782f1b69-31a8-44e0-94a4-b78426c86a31.

Panebianco, A. (1988). Political Parties: Organization and Power. Cambridge: Cambridge University Press.

Payne, S. (2018). Ukip's transformation into a far-right party is complete. Financial Times. Retrieved from: https://www.ft.com/content/c43857ca-ef16-11e8-89c8-d36339d835c0.

Pirro, A.L.P. (2019). Ballots and barricades enhanced: Far-right 'movement parties' and movementelectoral interactions. Nations and Nationalism, 25(3): 782-802.

Pirro, A.L.P., \& Castelli Gattinara, P. (2018). Movement parties of the far right: The organization and strategies of nativist collective actors. Mobilization: An International Quarterly, 23(3): $367-383$.

Pirro, A.L.P., \& Taggart, P. (2018). The populist politics of Euroscepticism in times of crisis: A framework for analysis. Politics, 38(3): 253-262.

Pirro, A.L.P., Pavan, E., Fagan, A. \& Gazsi, D. (2019). Close ever, distant never? Integrating protest event and social network approaches into the transformation of the Hungarian far right'. Party Politics. doi: 10.1177/1354068819863624. 
Puschmann, C., \& Scheffler, T. (2016). Topic modeling for media and communication research: $A$ short primer (Report No. 2016-05). Berlin: Das Alexander von Humboldt Institut für Internet und Gesellschaft.

Roesslein, J. (2017, November 10). Tweepy Documentation, release 3.5.0. Retrieved from https://buildmedia.readthedocs.org/media/pdf/tweepy/v3.5.0/tweepy.pdf.

Sheafer, T., Shenhav, S. R., Takens, J., \& Van Atteveldt, W. (2014). Relative political and value proximity in mediated public diplomacy: The effect of state-level homophily on international frame building. Political Communication, 31(1), 149-167.

Spence, A., \& Di Stefano, M. (2019, May 8). Under Siege For His Comments About Rape, UKIP's Star Candidate Carl Benjamin Has Recruited Milo Yiannopoulos To Join His Campaign. BuzzFeed. Retrieved from: https://www.buzzfeed.com/alexspence/ukips-european-electioncampaign-has-a-new-recruit-milo.

Stier, S., Bleier, A., Lietz, H., \& Strohmaier, M. (2018). Election Campaigning on Social Media: Politicians, Audiences, and the Mediation of Political Communication on Facebook and Twitter. Political Communication, 35(1), 50-74.

Stockemer, D., \& Barisione, M. (2017). The 'new' discourse of the Front National under Marine Le Pen: A slight change with a big impact. European Journal of Communication, 32(2), 100115.

Taggart, P. (1998). A touchstone of dissent: Euroscepticism in contemporary Western European party systems. European Journal of Political Research, 33(3): 363-388.

Usherwood, S. (2016). The UK Independence Party: The dimensions of mainstreaming. In T. Akkerman, S.L. de Lange, and M. Rooduijn (Eds.) Radical Right-Wing Populist Parties in Western Europe (pp. 247-267). London: Routledge.

Usherwood, S. (2019). Shooting the fox? UKIP's populism in the post-Brexit era. West European Politics, 42(6): 1209-1229.

UKIP (2018). Rules of Procedure. Retrieved from: https://www.ukip.org/uploads/party rules.pdf.

Van Kessel, S., \& Castelein, R. (2016). Shifting the blame. Populist politicians' use of Twitter as a tool of opposition. Journal of Contemporary European Research, 12(2): 594-614.

Walker, P. (2018a, December 4). Nigel Farage quits Ukip over its anti-Muslim fixation. Guardian. Retrieved from https://www.theguardian.com/politics/2018/dec/04/nigel-farage-quits-ukipover-fixation-anti-muslim-policies. 
Walker, P. (2018b, August 2). Ukip membership surges 15\% in a month. Guardian. Retrieved from https:/www.theguardian.com/politics/2018/aug/02/ukip-membership-surges-15-per-cent-ina-month.

Walker, P. (2018c, June 25). Ukip welcomes social media activists linked to 'alt-right' into party. Guardian. Retrieved from https:/www.theguardian.com/politics/2018/jun/25/ukipwelcomes-social-media-activists-linked-to-alt-right-into-party.

Walker, P., \& Halliday, J. (2019, March 3). Revealed: Ukip membership surge shifts party to far right. Guardian. Retrieved from https:/www.theguardian.com/world/2019/mar/03/newukip-members-shifting-party-far-right.

Wickham, H. (2016). Ggplot2: Elegant Graphics for Data Analysis. New York: Springer-Verlag.

Widfeldt, A. (2008). Party change as a necessity: The case of the Sweden Democrats. Representation, 44(3), 265-276. 
Tables

Table 1. Descriptive statistics of the Twitter pages of UKIP and WPP, per leader and total.

\begin{tabular}{|c|c|c|c|c|c|c|c|c|}
\hline & UKIP Farage & UKIP James & UKIP Nuttal & UKIP Crowther & UKIP Bolton & UKIP Batten & UKIP total & WPP total \\
\hline $\begin{array}{l}\text { Followers (by end } \\
\text { of leadership) }\end{array}$ & 139168 & 140833 & 165408 & 173123 & 179963 & 212488 & 212000 & 6152 \\
\hline Data timeline & $\begin{array}{l}01 / 01 / 15-16 / 09 / 16 \\
05 / 10 / 16-28 / 11 / 16\end{array}$ & $16 / 09 / 16-04 / 10 / 16$ & $28 / 11 / 16-09 / 06 / 17$ & $09 / 06 / 17-28 / 09 / 17$ & $29 / 09 / 17-17 / 02 / 18$ & $17 / 02 / 18-02 / 06 / 19$ & $01 / 01 / 15-10 / 05 / 19$ & $03 / 07 / 18-10 / 05 / 19$ \\
\hline $\begin{array}{l}\text { Tweets (incl. } \\
\text { replies) }\end{array}$ & 8332 & 222 & 1315 & 188 & 620 & 1691 & 12368 & 3731 \\
\hline $\begin{array}{l}\text { Tweets (excl. } \\
\text { replies) }\end{array}$ & 8315 & 222 & 1309 & 174 & 603 & 1537 & 12160 & 1665 \\
\hline $\begin{array}{l}\text { Percentage tweets } \\
\text { (excl. replies) }\end{array}$ & 99.80 & 100 & 99.54 & 92.55 & 97.26 & 90.89 & 98.33 & 44.63 \\
\hline $\begin{array}{l}\text { Tweets (excl. } \\
\text { URLs) }\end{array}$ & 7525 & 188 & 1128 & 124 & 507 & 1344 & 10816 & 914 \\
\hline $\begin{array}{l}\text { Mean likes per } \\
\text { tweet excl. replies } \\
(S D)\end{array}$ & $\begin{array}{c}39.07 \\
(49.04)\end{array}$ & $\begin{array}{l}36.05 \\
(44.70)\end{array}$ & $\begin{array}{c}67.06 \\
(87.21)\end{array}$ & $\begin{array}{c}87.40 \\
(119.76)\end{array}$ & $\begin{array}{c}112.55 \\
(132.41)\end{array}$ & $\begin{array}{c}382.15 \\
(562.16)\end{array}$ & $\begin{array}{c}89.73 \\
(237.05)\end{array}$ & $\begin{array}{c}59.44 \\
(165.46)\end{array}$ \\
\hline $\begin{array}{l}\text { Mean replies per } \\
\text { tweet }(S D)\end{array}$ & $\begin{array}{c}5.90 \\
(8.33)\end{array}$ & $\begin{array}{c}3.18 \\
(5.11)\end{array}$ & $\begin{array}{c}12.00 \\
(25.10)\end{array}$ & $\begin{array}{c}14.43 \\
(16.29)\end{array}$ & $\begin{array}{c}19.45 \\
(40.60)\end{array}$ & $\begin{array}{c}41.84 \\
(81.24)\end{array}$ & $\begin{array}{c}11.84 \\
(34.31)\end{array}$ & $\begin{array}{c}5.84 \\
(14.87)\end{array}$ \\
\hline $\begin{array}{l}\text { Mean retweets per } \\
\text { tweet excl. replies } \\
(S D)\end{array}$ & $\begin{array}{l}45.05 \\
(61.46)\end{array}$ & $\begin{array}{c}23.33 \\
(32.47)\end{array}$ & $\begin{array}{l}41.29 \\
(54.98)\end{array}$ & $\begin{array}{l}46.42 \\
(55.93)\end{array}$ & $\begin{array}{c}56.04 \\
(64.55)\end{array}$ & $\begin{array}{c}175.76 \\
(262.42)\end{array}$ & $\begin{array}{c}61.34 \\
(117.42)\end{array}$ & $\begin{array}{c}18.67 \\
(62.86)\end{array}$ \\
\hline
\end{tabular}


Table 2. Dictionaries.

\begin{tabular}{|l|l|}
\hline Topic & Words \\
\hline Europe & $\begin{array}{l}\text { ("eu*", "brussel*", "lisbon treaty", "superstate", "autocratic", "bureaucrats", "withdraw*", } \\
\text { "membership", "sovereign*", "brexit", "negotiation*", "european integration*", "ecb", "anti-eu", } \\
\text { "no2eu", "greece", "turkey") }\end{array}$ \\
\hline Immigration & $\begin{array}{l}\text { ("immigra*", "migra*", "foreigner*", "border", "asylum", "refugee*", "illegal*", "racist", "diversity", } \\
\text { "multicultural*") }\end{array}$ \\
\hline Islam & $\begin{array}{l}\text { ("islam*","burqa", "niqab", "mosque*", "sharia", "muslim*", "imam*", "preacher*", "terror*", } \\
\text { Gender }\end{array}$ \\
\hline
\end{tabular}

Table 3. Recall, precision, and F1 measures for the dictionaries.

\begin{tabular}{|l|c|c|c|}
\hline & Recall & Precision & F1 \\
\hline Europe & 0.85 & 0.85 & 0.85 \\
\hline Immigration & 1.00 & 0.95 & 0.97 \\
\hline Islam & 0.80 & 0.88 & 0.84 \\
\hline Gender & 0.92 & 0.92 & 0.92 \\
\hline Total & 0.88 & 0.88 & 0.88 \\
\hline
\end{tabular}

Table 4. Percentage of tweets on Europe, immigration, Islam, and gender before and during Batten on the page of UKIP (only leaders after Farage included) $(* \mathbf{p}<0.017, * * p<0.003$, $* * * \mathbf{p}<\mathbf{0 . 0 0 0 3 )}$.

\begin{tabular}{|l|c|c|c|c|c|}
\hline & \multicolumn{2}{|c|}{ Before Batten } & \multicolumn{2}{c|}{ Batten } & T (df=3289) \\
\hline & Mean & SD & Mean & SD & \\
\hline Europe & 0.209 & $(0.406)$ & 0.457 & $(0.498)$ & $-15.69^{* * *}$ \\
\hline Immigration & 0.0539 & $(0.226)$ & 0.0379 & $(0.191)$ & 2.12 \\
\hline Islam & 0.0149 & $(0.121)$ & 0.0223 & $(0.148)$ & -1.58 \\
\hline Gender & 0.00924 & $(0.0957)$ & 0.00744 & $(0.0860)$ & 0.55 \\
\hline
\end{tabular}


Table 5. Percentage of tweets on Europe, immigration, Islam, and gender before and after the Brexit referendum $(* \mathbf{p}<0.017, * * p<0.003, * * * p<0.0003)$.

\begin{tabular}{|l|c|c|c|c|c|}
\hline & \multicolumn{2}{|c|}{ Before referendum } & \multicolumn{2}{c|}{ After referendum } & T (df=10814) \\
\hline & Mean & SD & Mean & SD & \\
\hline Europe & 0.271 & $(0.444)$ & 0.305 & $(0.460)$ & $-3.74^{* * *}$ \\
\hline Immigration & 0.0862 & $(0.281)$ & 0.045 & $(0.208)$ & $7.74^{* * *}$ \\
\hline Islam & 0.00912 & $(0.095)$ & 0.0165 & $(0.127)$ & $-3.38^{* *}$ \\
\hline Gender & 0.00470 & $(0.0684)$ & 0.008 & $(0.088)$ & -2.03 \\
\hline
\end{tabular}

Table 6. Percentage of tweets on Europe, immigration, Islam, and gender for Batten's UKIP and WPP $(* \mathbf{p}<0.017, * * \mathbf{p}<0.003, * * * p<0.0003)$.

\begin{tabular}{|l|c|c|c|c|c|}
\hline & \multicolumn{2}{|c|}{ UKIP } & \multicolumn{2}{c|}{ WPP } & T (df=2256) \\
\hline & Mean & SD & Mean & SD & \\
\hline Europe & 0.457 & $(0.498)$ & 0.0996 & $(0.300)$ & $19.42^{* * *}$ \\
\hline Immigration & 0.0379 & $(0.191)$ & 0.0624 & $(0.242)$ & $-2.67^{*}$ \\
\hline Islam & 0.0223 & $(0.148)$ & 0.0799 & $(0.271)$ & $-6.49^{* * *}$ \\
\hline Gender & 0.007 & $(0.080)$ & 0.0284 & $(0.166)$ & $-3.92^{* * *}$ \\
\hline
\end{tabular}


Figures

Figure 1. Proportion of tweets on Europe, immigration, Islam, and gender on the page of UKIP.

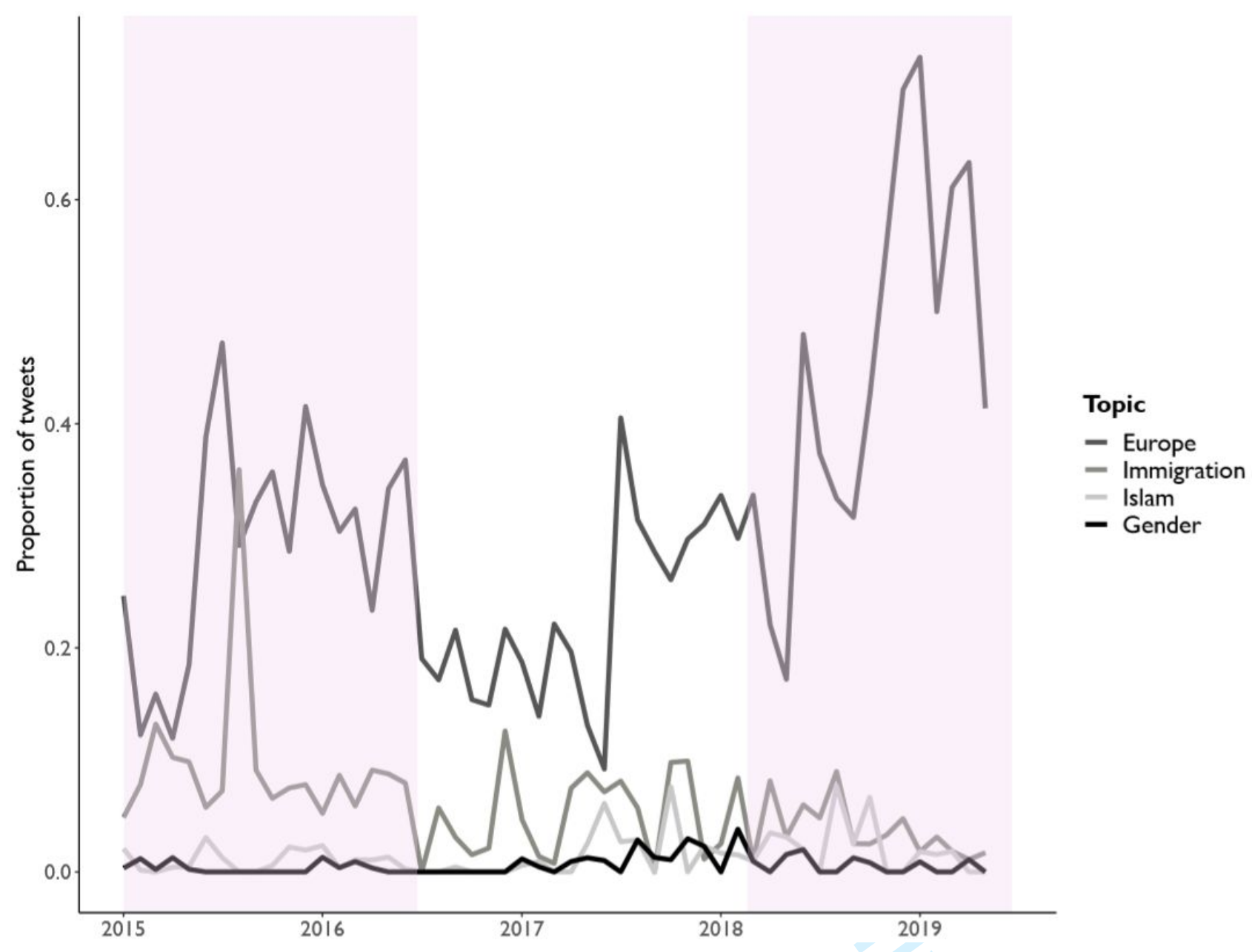

Note: The figure distinguishes between three periods. The first period refers to the phase preceding the Brexit referendum (Farage leadership), the second period to the post-referendum leadership periods (except Batten), and the third period to Batten's leadership. 
Figure 2. Proportion of tweets on Europe, immigration, Islam, and gender on the Twitter pages of UKIP and WPP during Batten's leadership.
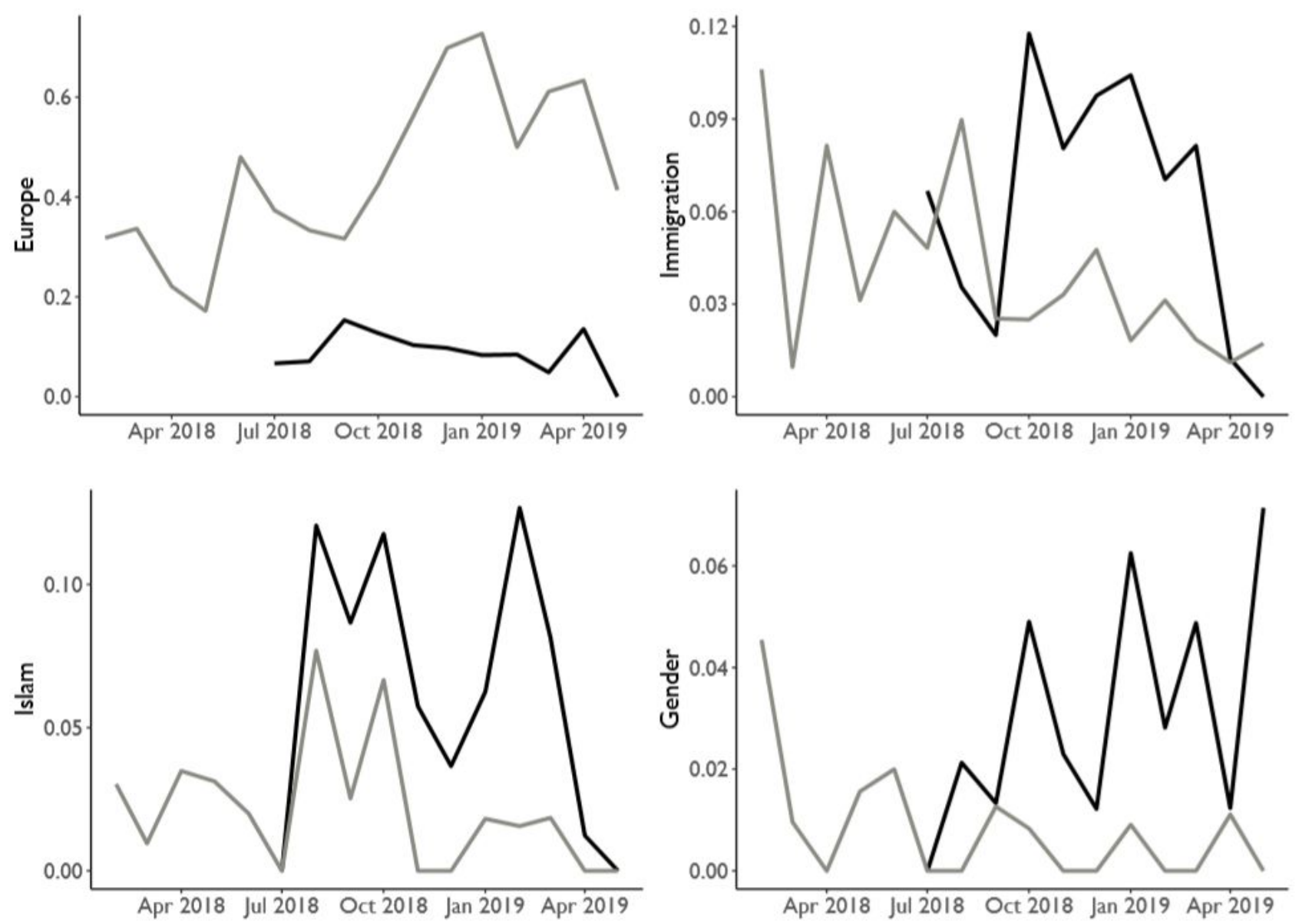

$$
\text { Page - WPP - UKIP }
$$

